\section{Toxicological and}

Environmental

Chemistry

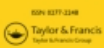

Toxicological \& Environmental Chemistry

ISSN: 0277-2248 (Print) 1029-0486 (Online) Journal homepage: http://www.tandfonline.com/loi/gtec20

\title{
Water quality supply in a Portuguese teaching hospital: monitoring and studies on detection of critical points
}

\section{Pedro Norton, Joana Amaro, Natália Martins \& Manuela Vieira da Silva}

To cite this article: Pedro Norton, Joana Amaro, Natália Martins \& Manuela Vieira da Silva (2017) Water quality supply in a Portuguese teaching hospital: monitoring and studies on detection of critical points, Toxicological \& Environmental Chemistry, 99:1, 171-180, DOI: 10.1080/02772248.2016.1164423

To link to this article: https://doi.org/10.1080/02772248.2016.1164423

\section{曲 Published online: 30 Mar 2016.}

\section{Submit your article to this journal $₫$}

Џ Article views: 66

View Crossmark data ¿ 


\title{
Water quality supply in a Portuguese teaching hospital: monitoring and studies on detection of critical points
}

\author{
Pedro Norton ${ }^{a, b}$, Joana Amaro ${ }^{a, c}$, Natália Martins ${ }^{b}$ and Manuela Vieira da Silva ${ }^{d}$ \\ ${ }^{a}$ EPIUnit - Institute of Public Health, University of Porto, Porto, Portugal; ${ }^{b}$ Occupational Health Service of the \\ Hospital Epidemiology Centre, São João Hospital Centre, Porto, Portugal; 'Department of Clinical Epidemiology, \\ Predictive Medicine and Public Health, University of Porto Medical School, Porto, Portugal; ' ${ }^{\text {Environmental Health }}$ \\ Department, School of Allied Health Technologies of Polytechnic Institute of Porto (ESTSP.IPP), Vila Nova de Gaia, \\ Portugal
}

\begin{abstract}
Surveillance of drinking water quality is extremely important to human health, assuming greater relevance in hospital environments, especially to those individuals who are immunocompromised. This study is aimed to determine the effect of increasing free chlorine $(\mathrm{Cl})$ concentration in a hospital water network in regard to water quality monitoring and microbial growth control, between 2010 and 2013 in Porto. The average of free $\mathrm{Cl}$ concentration in the period under analysis showed some heterogeneity per floor, varying between 0.84 and $1.25 \mathrm{mg} / \mathrm{L}$. In addition, there was a rise in proportion of samples that exceeded WHO guidelines (free $\mathrm{Cl} \geq 0.5 \mathrm{mg} / \mathrm{L}$ ), particularly in the last two years of the same period. With respect to microbial analysis, $22.4 \%$ of the samples were positive for Legionella spp., $6.4 \%$ for Pseudomonas aeruginosa, $15 \%$ and $30.4 \%$ for aerobic plate counts at 36 and $22{ }^{\circ} \mathrm{C}$, respectively. The proportion of positive samples decreased throughout the period under analysis, in particular for Legionella spp. (41.7\% in 2010 vs. non-detectable in 2013) and P. aeruginosa (10.8\% in 2010 vs. $3.3 \%$ in 2013). These results are in accordance with the gradual rise in free $\mathrm{Cl}$ concentration $(0.78 \pm$ $0.94 \mathrm{mg} / \mathrm{L}$ in 2010 vs. $1.16 \pm 0.51 \mathrm{mg} / \mathrm{L}$ in 2013). In conclusion, a suitable plan for drinking water quality was instituted which resulted in reducing microbiological growth in the waterwork network, improving public health protection. However, the detection of critical points associated with lower levels of free $\mathrm{Cl}$ were found on certain floors/points-of-use, requiring the need to improve the monitoring water treatment system and/or implementation of additional technologies.
\end{abstract}

\section{ARTICLE HISTORY}

Received 14 January 2016

Accepted 6 March 2016

\section{KEYWORDS}

Water quality; hospitals; chlorine; Legionella spp.; Pseudomonas aeruginosa

\section{Introduction}

Hospital water networks are one of the main sources of nosocomial infections (Department of Health 2006; HPSC 2015). Two of the most common bacterial agents are Legionella spp. and Pseudomonas aeruginosa (Leprat et al. 2003; Sehulster et al. 2003) - 
water persistent gram-negative bacteria. Colonization of the respiratory tract by these bacteria may progress to pneumonia and/or other severe infections (Sehulster et al. 2003).

Legionella spp. is a waterborne pathogen that is normally transmitted through aerosols and a common species found in hospital water supplies (Rafiee et al. 2014). The prevalence of Legionella-related diseases in a hospital environment is considerably high when compared to the general community (33.3\% vs. 7.5\%) (Tesauro et al. 2010). The presence of Legionnaires' disease in hospitals globally reached 47\% (Joly et al. 2006; Yu 2008; Rafiee et al. 2014). However, this may be an underestimation due to advances in identification techniques required for detection, which were not available in the past and also the unspecific nature of Legionella-related diseases' clinical manifestations (Fields, Benson, and Besser 2002; Rafiee et al. 2014; HPSC 2015).

The Hospital studied in Porto is supplied by the public water network whose quality is guaranteed by the city council. However, since it has a $55 \mathrm{~km}$ network with more than 50 years at some points, it is difficult to assure water quality in all its extension. On the other hand, hospitalized patients consume this water on a daily basis (bottled water is not provided), including immunocompromised patients and children (through infant's formula milk). It should be noted that the lethality rate associated with Legionella spp. in immunocompromised patients is considerably high (Flannery et al. 2006), as well as in patients undergoing hemodialysis (Vorbeck-Meister et al. 1999). Patients suffering from burns and neutropenia have higher morbidity and mortality rates associated with Pseudomonas (Sehulster et al. 2003). Therefore, health care facilities have a special responsibility controlling disinfection and water quality consumed by patients or used in their personal hygiene, to prevent nosocomial infections namely Legionella and Pseudomonas.

In Portugal, Legionella spp. water analysis is mandatory in a context of inner air quality assessment, but there is no specific legislation concerning water used for human consumption and for hemodialysis. Even considering the implementation of an effective drinking water disinfection control system, the hospital needs to have the practice of Legionella monitoring. WHO recommends, for hospitals that use systematic water disinfection, that the water cultures of Legionella be verified every three months for efficacy of disinfection (Bartram et al. 2007).

Different factors are required to be studied when selecting the most suitable water disinfection method in health care facilities in order to guarantee water quality (Zhang et al. 2007). No method can guarantee absolute total disinfection and when colonization occurs, it is extremely difficult to eliminate it (Scaturro et al. 2007; Lin, Stout, and Yu 2011; Cristino, Legnani, and Leoni 2012; Orsi et al. 2014). Chlorine (Cl) is widely used as a disinfectant in Portuguese water systems (Diegues 2013) and it is considered efficient. However, this method encompasses several disadvantages, including (1) corrosion (necessary to add other anti-corrosive chemical products and silicate material), (2) difficulty in penetrating the biofilm, (3) high levels of Legionella resistance, and (4) potential of production of disinfection by-products (DBPs), as trihalometanes (THM) (Lin, Stout, and Yu 2011; Diegues 2013; Hrudey et al. 2015). Further, it is well known that the biofilms in drinking water systems may become transient or long-term habitats for particular micro-organisms, such as P. aeruginosa (Wingender and Flemming 2011).

In 2005, a Drinking Water Quality Control Working Group was created in a university hospital which included microbiologists, hygiene and safety technicians, and infectious 
disease specialists. The initial goal was to keep the free $\mathrm{Cl}$ reference range between 0.2 and $0.6 \mathrm{mg} / \mathrm{L}$, according to the national legislation (Decree-Law 306/2007). However, considering the type of patients treated, the structural dimension of the building (with a $55 \mathrm{~km}$ water network), and previous history of microbial growth (including P. aeruginosa and Legionella spp.), it was decided in 2012 to increase the reference range according to WHO recommendations.

Thus, the aim of this study was to determine the effect of increasing free $\mathrm{Cl}$ concentration in a hospital water network in regard to microbial growth control, namely P. aeruginosa and Legionella spp.

\section{Material and methods}

\section{Hospital characteristics}

The hospital under analysis is one of the largest in Portugal with approximately 5600 workers. It is a university hospital constituted by a main building with over 50 years of existence. The hospital is divided into 11 floors, 2 of which are underground, and has five satellite buildings. The hospital has approximately 1100 beds and more than 50 medical and surgical specialties, as well as a variety of complementary means of diagnosis and therapeutic support.

The hospital has a water network of more than $55 \mathrm{~km}$ that is supplied by the public water network with seven water reservoirs and a sodium hypochlorite injection system used for disinfestation in three of these reservoirs. There is a booster injection in a technical area located on the fourth floor. The distribution network is mixed - it is constituted by both new and outdated pipes of different types of materials such as cross-linked polyethylene (PEX) and iron.

\section{Water monitoring plan and strategy}

With regard to the parameters under analysis, free $\mathrm{Cl}$ and temperature levels were assessed daily in at least 22 different collection points including point-of-use outlets of the supply network such as taps, sinks, showers, reservoirs, and water fountains distributed and covering the entire hospital. Microbiological parameters such as aerobic plate count (APC) at 22 and $36{ }^{\circ} \mathrm{C}$ as well as $P$. aeruginosa were analyzed monthly at 21 collection points. Legionella analysis was performed once a month.

\section{Chlorine and temperature monitoring}

Free $\mathrm{Cl}$ concentrations were measured in a separate sample bottle. Temperature was measured with a handheld thermometer (Hanna-Instruments brand) directly at the point-ofuse outlet. Residual free $\mathrm{Cl}$ was determined by using the N,N-diethyl-p-phenylenediamine method with a colorimeter and test kit (HACH LANGE brand, the Pocket Colorimeter model). For determination of the $\mathrm{Cl}_{2}$ concentration, $5 \mathrm{~mL}$ water samples were collected and after assessment of the white portion, the sample was diluted and added to a conductor, DPD-Free Chlorine. The results were expressed in $\mathrm{mg} / \mathrm{L}$ of $\mathrm{Cl}_{2}$. 


\section{Sample collection and microbiological analysis}

The collection and processing of the samples were carried out by an accredited lab $\left(\right.$ Sagilab $\left.{ }^{\circledR}\right)$. For this purpose, each sample was collected into a sterile $1 \mathrm{~L}$ bottle containing $0.5 \mathrm{~mL} 0.1 \mathrm{~N}$ sodium thiosulfate to neutralize free $\mathrm{Cl}$, and then conditioned at control temperature.

The microbiological analyses were performed according to the following standards and technical instructions: (1) APC, quantification at $36^{\circ} \mathrm{C}$ (ISO 6222:1999); (2) APC, quantification at $22{ }^{\circ} \mathrm{C}$ (ISO 6222:1999); (3) P. aeruginosa survey and quantification (ISO 16266:2006); (4) intestinal Enterococcus spp. survey and quantification (ISO 7899-2:2000); (5) Legionella spp. survey and identification (ISO 11731:1998); (6) total coliforms survey and quantification (pema028, 2012-03); (7) Escherichia coli survey and quantification (pema028, 2012-03); (8) Staphylococcus aureus survey and quantification (XP T 90-412, 2014-05); and (9) Clostridium perfringens survey and quantification (pema008, 2012-10).

According to the Portuguese legal law for drinking water quality (Decree-Law 306/2007), the following microbiological references were used: APC at $36^{\circ} \mathrm{C}, 20$ colony forming units/ $\mathrm{mL}(\mathrm{CFU} / \mathrm{mL}) ; \mathrm{APC}$ at $22{ }^{\circ} \mathrm{C}, 100 \mathrm{UFC} / \mathrm{mL} ; 100 \mathrm{CFU} / \mathrm{L}$ for Legionella spp., and for cooling towers, $1000 \mathrm{CFU} / \mathrm{L}$. P. aeruginosa reference level was internally established as $0 \mathrm{CFU} / \mathrm{mL}$.

\section{Statistical analysis}

Statistical analyses were performed with IBM SPSS statistics 21.0. Chi-Square test or Fisher's exact test was used to analyze microbial qualitative data. Residual $\mathrm{Cl}$ qualitative data was analyzed by one-way analysis of variance (ANOVA).The criterion for significance was set at $p<0.05$.

\section{Results}

Between 2010 and 2013, the mean free $\mathrm{Cl}$ concentration per floor showed some differences varying between 0.84 and $1.25 \mathrm{mg} / \mathrm{L}$ (Table 1 ), exceeding the national recommendations, but is in accordance with WHO guidelines. A proportion of samples with a nondetectable free $\mathrm{Cl}$ concentration $(0 \mathrm{mg} / \mathrm{L})$ was found on the eighth and second floors (3.5\% and $3.3 \%$, respectively), and on the first and sixth floor, $0.2 \%$ of the water samples reaching to $11 \mathrm{mg} \mathrm{Cl} / \mathrm{L}$ (Table 1 ). In addition, there was a rise in proportion of samples that exceeded WHO guidelines (free $\mathrm{Cl} \geq 0.5 \mathrm{mg} / \mathrm{L}$ ), particularly in the last two years of the same period (Figure 1). With respect to microbial analysis, 22.4\% samples were positive for Legionella spp., 6.4\% for P. aeruginosa, and 15\% and 30.4\% for APC at 36 and 22 ${ }^{\circ} \mathrm{C}$, respectively (Figure 2). The proportion of positive samples decreased throughout the period under analysis, in particular for Legionella spp. (41.7\% in 2010 vs. non-detectable percentage in 2013 ) and P. aeruginosa (10.8\% in 2010 vs. $3.3 \%$ in 2013 ). These results are in accordance with gradual elevation in free $\mathrm{Cl}$ concentration $(0.78 \pm 0.94 \mathrm{mg} / \mathrm{L}$ in 2010 vs. $1.16 \pm 0.51 \mathrm{mg} / \mathrm{L}$ in 2013 ) (Table 2 ).

$P$. aeruginosa was detected in 7 of 11 floors, with 4 floors showing more than $10 \%$ positive samples, namely $2^{\text {nd }}$ basement, $1^{\text {st }}, 3^{\text {rd }}$, and $8^{\text {th }}$ floors. In two of these floors (first and third), positive samples for Legionella were also detected (above $100 \mathrm{CFU} / \mathrm{mL}$ ) (Table 3). These results were consistent with APC results at 22 and $36^{\circ} \mathrm{C}$, which also demonstrated 
Table 1. Free chlorine concentration ( $\left.\mathrm{mg} \mathrm{Cl}_{2} / \mathrm{L}\right)$ per floor (2010-2013).

\begin{tabular}{lcccccc}
\hline & & \multicolumn{5}{c}{ Free chlorine $\left(\mathrm{mg} \mathrm{Cl}_{2} / \mathrm{L}\right)$} \\
\cline { 3 - 7 } $\begin{array}{l}\text { Floor } \\
\text { building }\end{array}$ & $\begin{array}{c}\text { No. of } \\
\text { samples }(N)\end{array}$ & Mean \pm SD & Min & $\begin{array}{c}\text { No. of samples corresponding } \\
\text { to min concentration (\%) }\end{array}$ & Max & $\begin{array}{c}\text { No. of samples corresponding } \\
\text { to max concentration (\%) }\end{array}$ \\
\hline 02 & 1223 & $1.02 \pm 0.96$ & 0.00 & $16(1.3)$ & 11.00 & $1(0.1)$ \\
01 & 1653 & $1.00 \pm 0.88$ & 0.00 & $25(1.5)$ & 11.00 & $1(0.1)$ \\
1 & 3894 & $1.02 \pm 0.94$ & 0.00 & $79(2.0)$ & 11.00 & $9(0.2)$ \\
2 & 4480 & $0.84 \pm 0.83$ & 0.00 & $148(3.3)$ & 11.00 & $4(0.1)$ \\
3 & 1878 & $0.86 \pm 0.68$ & 0.00 & $28(1.5)$ & 11.00 & $2(0.1)$ \\
4 & 1894 & $0.98 \pm 0.89$ & 0.00 & $21(1.1)$ & 11.00 & $2(0.1)$ \\
5 & 2504 & $0.92 \pm 0.67$ & 0.00 & $50(2.0)$ & 7.00 & $1(0.0)$ \\
6 & 1962 & $1.25 \pm 1.10$ & 0.00 & $8(0.4)$ & 11.00 & $3(0.2)$ \\
7 & 2838 & $1.09 \pm 1.04$ & 0.00 & $51(1.8)$ & 11.00 & $4(0.1)$ \\
8 & 2628 & $1.03 \pm 0.95$ & 0.00 & $94(3.5)$ & 11.00 & $1(0.0)$ \\
9 & 1651 & $1.05 \pm 0.84$ & 0.00 & $21(1.3)$ & 11.00 & $2(0.1)$ \\
Roofing & nd & nd & nd & nd & nd & nd \\
\hline
\end{tabular}

Note: nd - not determined.

SD - standard deviation.

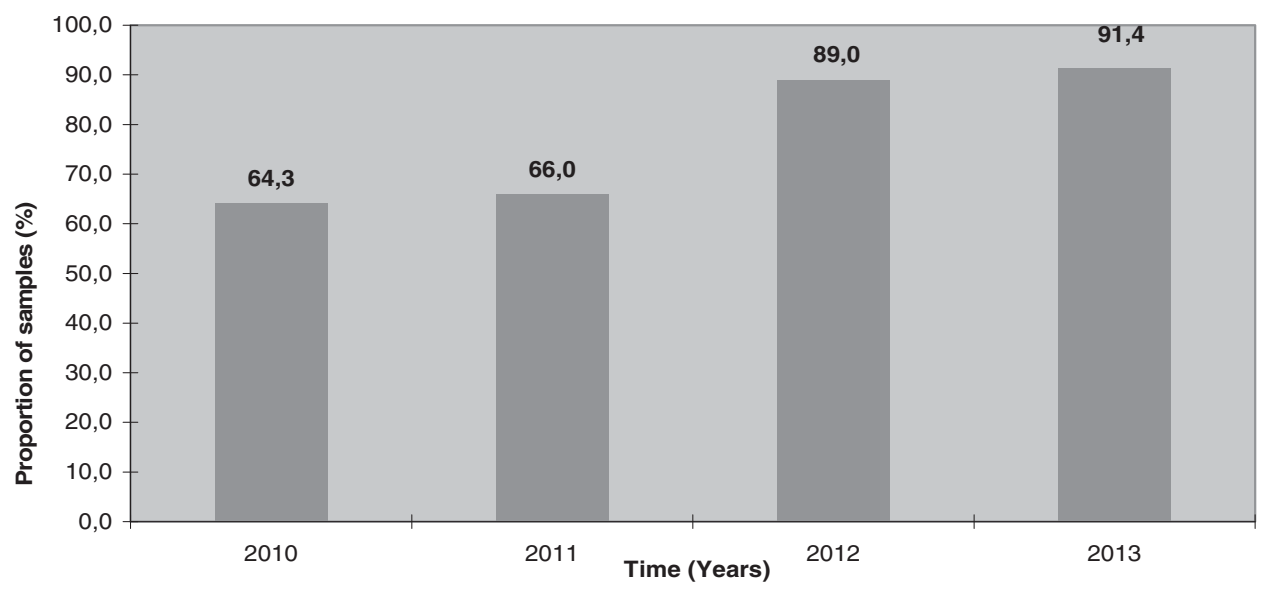

Figure 1. Proportion of water samples that met goals $\left(\geq 0.5 \mathrm{mg} / \mathrm{L} \mathrm{Cl}_{2}\right)$ in the period $2010-2013$.

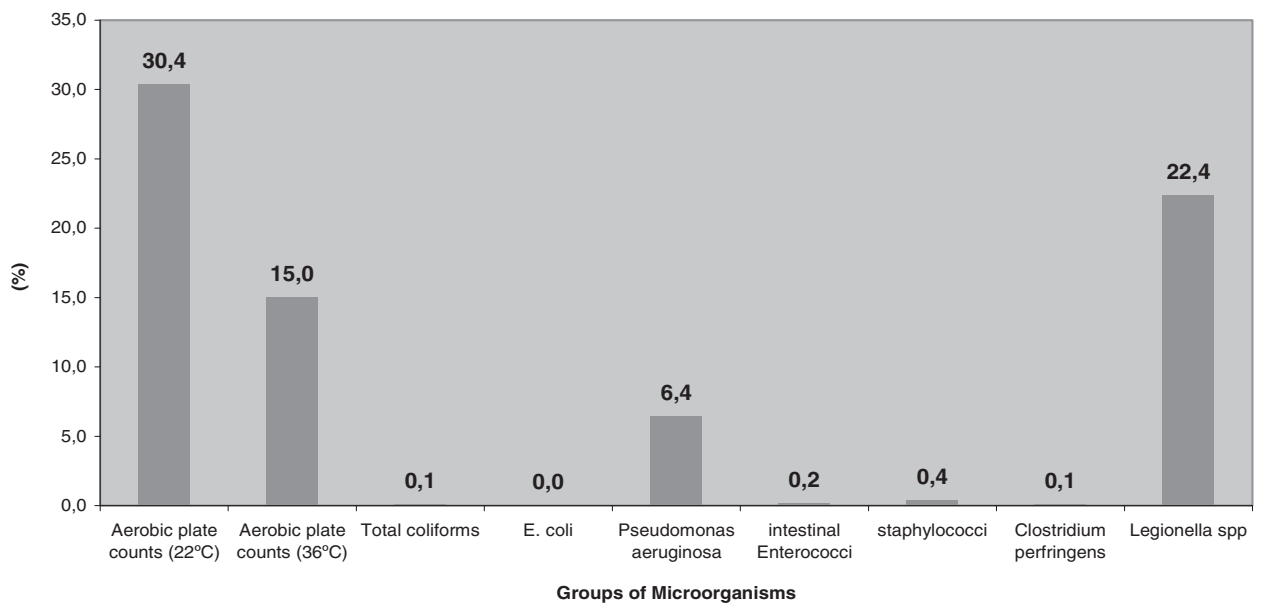

Figure 2. Proportion (\%) of samples above reference for microbial growth in the period 2010-2013. 

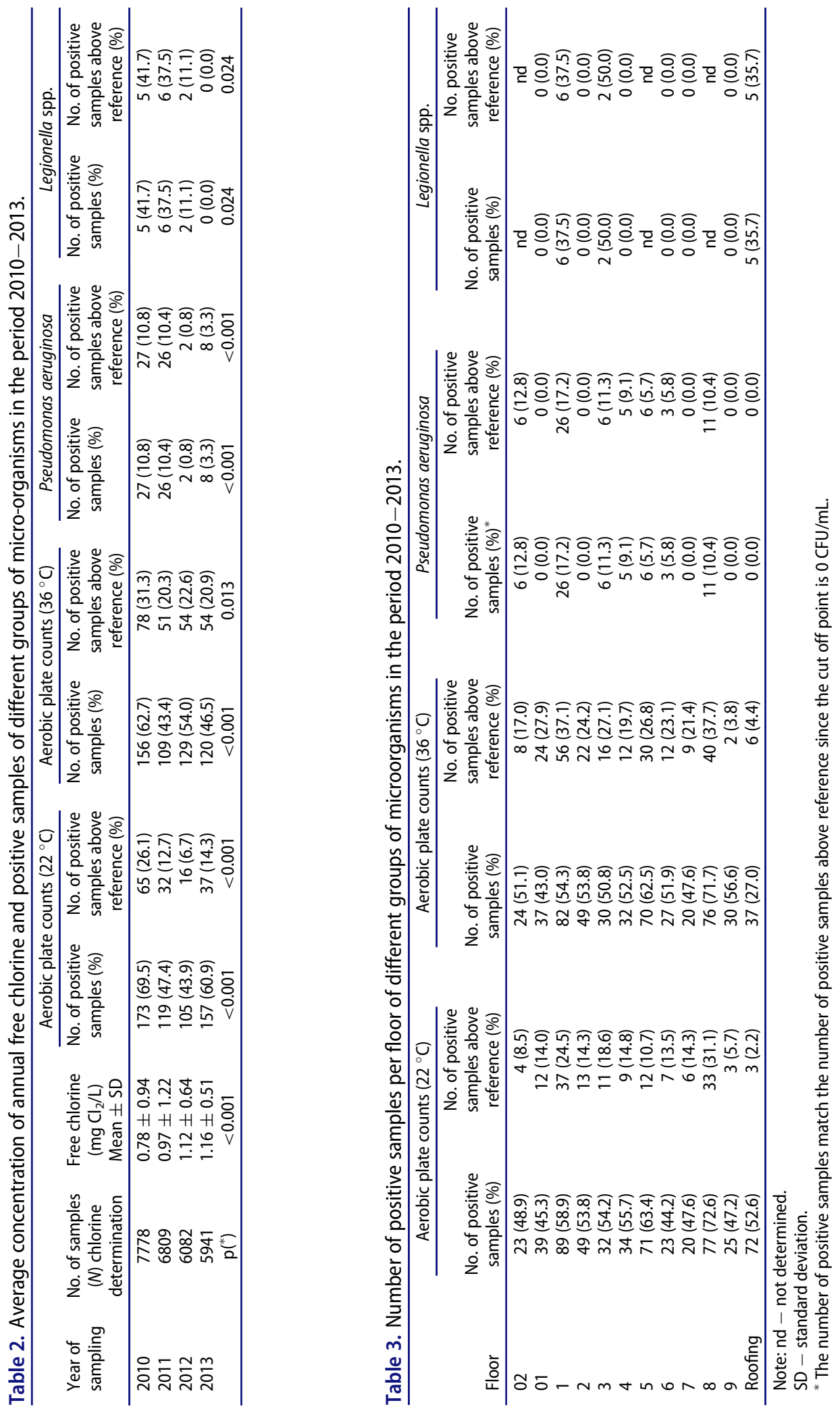
a higher proportion of samples above the reference limit in most of the same floors (first, third, and eighth).

\section{Discussion}

Hospital water networks are one of the main sources of nosocomial infections (Department of Health 2006; HPSC 2015). Knowledge of water distribution, identification of critical areas, and selection of a disinfection method are particularly the important measures to control microbiological growth and prevent nosocomial infections. Knowledge of water distribution may be a difficult task in old hospitals with extensive distribution networks, constituted by new and outdated pipes of different types of materials.

Water networks of considerable size (Ozerol et al. 2006; Ghotaslou et al. 2013), old and complex plumbing, as well as the use of reduced-temperature water are characteristics that correlated with Legionella spp. exposure (Fields, Benson, and Besser 2002; Ozerol et al. 2006; Pancer, Rabczenko, and Stypulkowska-Misiurewicz 2006; Koziol-Montewka et al. 2008), and other bacteria, thus, representing a public health issue, as the increase in the amount of this bacteria in hospitals is proportional to the frequency of Legionnaires' disease (Kohler et al. 1999; Ghotaslou et al. 2013). In this particular case, the distribution system was comprised of a variety of materials used for piping, fitting, coating, valves, and appurtenances that promoted microbial growth. Pipe materials were found to influence biofilm accumulation through corrosion, release of compounds that support biological growth, and other surface characteristics (Stewart, McFeters, and Huang 2000). There is some evidence that pipe materials such as PVC and cross-linked polyethylene (PEX) may affect Legionella growth in water systems (van der Kooij, Veenendaal, and Scheffer 2005). Disturbances in water pressures or inadequate levels of chemical biocides create conditions that disrupt biofilms or allow Legionella and other waterborne pathogens to multiply. Lin, Stout, and $\mathrm{Yu}$ (2011) suggested that the use of the electronic faucets poses a potential risk for nosocomial infection-risk areas of hospital, due to the water-saving function of electronic faucets, since there was insufficient amount of water to flush and clean them.

In this study, several areas were identified as critical, namely the first floor, where the water network is obsolete and the collecting points were in most parts located at the louvers in the operating rooms. At these points, the water temperature is tepid, promoting bacteriological growth. With respect to microbial analysis between 2010 and 2013, 22.4\% of the samples were positive for Legionella spp., 6.4\% for P. aeruginosa, 15\% and 30.4\% for APC at 36 and $22{ }^{\circ} \mathrm{C}$, respectively. The high prevalence of Legionella and Pseudomonas may be due to relapses.

The total count of viable micro-organisms at 36 and $22{ }^{\circ} \mathrm{C}$ is an indicator of the disinfection status of the distribution network and drinking water. A high number of colonies presumably indicate the presence of biofilm. In some instances (namely to control Legionella spp. and P. aeruginosa growth), there was the need to promote chemical disinfection of the supply circuit, increasing free $\mathrm{Cl}$ above recommended values. On the other hand, in drinking water systems, all surfaces in contact with water may be colonized by microorganisms. Wingender and Flemming (2011) estimated that about 95\% of all microbial cells present in drinking water distribution systems exist as biofilms on pipe surfaces and only $5 \%$ occur in water phase. These micro-organisms might be opportunistic pathogens which harm humans, especially immunocompromised individuals (Wingender and 
Flemming 2011). After biofilm creation, micro-organisms grow in a matrix and are protected from external stressors, such as disinfection action and physical removal. Our study showed that $\mathrm{Cl}$, a low-cost widely used disinfectant, might be an effective method to control microbial growth. In fact, the gradual increase in $\mathrm{Cl}$ concentration was associated with an improvement in microbiological control of drinking water, even with respect to known Cl-resistant species such as Legionella and Pseudomonas.

Adverse health effects that may result from chronic exposure to mixtures of DBPs present in drinking waters may be linked to both the types and concentrations of DBPs involved (Hrudey et al. 2015). Depending on the characteristics of the source water and treatment processes used, both types and concentrations of DBP found in drinking waters vary substantially (Miltner et al. 2008; Schenck, Sivaganesan, and Rice 2009). However, the WHO states that the small amount of $\mathrm{Cl}$ typically used to disinfect water does not pose risks to human health, and has established a guideline value of $5 \mathrm{mg} / \mathrm{L}$ for $\mathrm{Cl}$ in drinking water, a value that is 'conservative', since no adverse effects at that concentration in drinking water were reported in studies reviewed by WHO (WCC 2008).

In conclusion, the increase of free $\mathrm{Cl}$ concentration resulted in a decrease in microbiological growth in the water network, potentially improving public health protection and reducing economic costs by streamlining current management practices.

\section{Acknowledgments}

The authors thank Occupational Health Department of S. João Hospital for participation concerning the water samples' collection and monitoring.

\section{Disclosure statement}

No potential conflict of interest was reported by the authors.

\section{References}

Bartram, J., Y. Chartier, J.V. Lee, K. Pond, and S. Surman-Lee., eds. 2007. Legionella and the Prevention of Legionellosis. Geneva: World Health Organization.

Cristino, S., P.P. Legnani, and E. Leoni. 2012. "Plan for the Control of Legionella Infections in Long-Term Care Facilities: Role of Environmental Monitoring." International Journal Hygiene and Environmental Health 215: 279-285.

Department of Health. 2006. Health Technical Memorandum 04-01: The Control of Legionella, Hygiene, "Safe" Hot Water, Cold Water and Drinking Water Systems. Part A: Design, Installation and Testing. Norwich: Estates and Facilities Division. https://www.gov.uk/government/uploads/ system/uploads/attachment_data/file/144147/HTM_04-01_Part_A.pdf

Diegues, P.V.M. 2013. Prevenção da Doença dos Legionários, Sistemas de Tratamento, Vantagens e desvantagens [Prevention of Legionnaires' Disease, Treatment Systems, Advantages and Disadvantages]. Portugal: Direção de Serviços de Prevenção da Doença e Promoção da Saúde. Editor, Direcção Geral de Saúde: Direcção Geral de Saúde 29.

Fields, B.S., R.F. Benson, and R.E. Besser. 2002. “Legionella and Legionnaires' Disease: 25 Years of Investigation." Clinical Microbiology Review 15: 506-526.

Flannery, B., L.B. Gelling, D.J. Vugia, J.M. Weintraub, J.J. Salerno, M.J. Conroy, V.A. Stevens, et al. 2006. "Reducing Legionella Colonization in Water Systems with Monochloramine." Emergent Infections Diseases 12: 588-596. 
Ghotaslou, R., F.Y. Sefidan, M.T. Akhi, M.H. Soroush, and M.S. Hejazi. 2013. "Detection of Legionella Contamination in Tabriz Hospitals by PCR Assay." Advanced Pharmaceutical Bulletin 3: $131-134$.

HPSC. 2015. "Guidelines for the Prevention and Control of Infection from Water Systems in Healthcare Facilities." Prepared by the Prevention and Control of Infection from Water Systems in Healthcare Facilities Sub-Committee of the HPSC Scientific Advisory Committee. http:// www.hpsc.ie/AboutHPSC/ScientificCommittees/Sub-CommitteesofHPSCSAC/WaterGuidelines Sub-Committee/File,14451,en.pdf

Hrudey, S.E., L.C. Backer, A.R. Humpage, S.W. Krasner, D.S. Michaud, L.E. Moore, P.C. Singer, and B.D. Stanford. 2015. "Evaluating Evidence for Association of Human Bladder Cancer with Drinking-Water Chlorination Disinfection By-Products." Journal of Toxicology and Environmental Health B 18: 213-241.

Joly, P., P. Falconnet, J. André, N. Weill, M. Reyrolle, F. Vandenesch, M. Maurin, J. Etienne, and S. Jarraud. 2006. "Quantitative Real-Time Legionella PCR for Environmental Water Samples: Data Interpretation.” Applied Environmental Microbiology 72: 2801-2808.

Kohler, J.R., M. Maiwald, P.C. Luck, J.H. Helbig, V. Hingst, and H.G. Sontag. 1999. "Detecting Legionellosis by Unselected Culture of Respiratory Tract Secretions and Developing Links to Hospital Water Strains." Journal of Hospital Infections 41: 301-311.

Koziol-Montewka, M., A. Magrys, N. Stojek, M. Palusinska-Szysz, and M. Danielak. 2008. "Monitoring Legionella Species in Hospital Water Systems. Link with Disease and Evaluation of Different Detection Methods." Annals of Agriculture and Environmental Medicine 15: 143-147.

Leprat, R., V. Denizot, X. Bertrand, and D. Talon. 2003. "Non-Touch Fittings in Hospitals: A Possible Source of Pseudomonas Aeruginosa and Legionella spp." Journal of Hospital Infections 53: 77.

Lin, Y.E., J.E. Stout, and V.L. Yu. 2011. "Controlling Legionella in Hospital Drinking Water: An Evidence-Based Review of Disinfection Methods." Infection Control Hospital Epidemiology 32: $166-173$.

Miltner, R.J., T.F. Speth, D.S. Richardson, S.W. Krasner, H.S. Weinberg, and J.E. Simmons. 2008. "Integrated Disinfection By-Products Mixtures Research: Disinfection of Drinking Waters by Chlorination and Azonation/Postchlorination Treatment Scenarios." Journal Toxicology and Environmental Health A 71: 1133-1148.

Orsi, J.B., M. Vitali, L. Marinelli, V. Ciorba, D. Tufi, A.D. Cimmuto, P. Ursillo, et al. 2014. "Legionella Control in the Water System of Antiquated Hospital Buildings by Shock and Continuous Hyperchlorination: 5 Years Experience." BMC Infectious Diseases 14: 394.

Ozerol, I.H., M. Bayraktar, Z. Cizmeci, R. Durmaz, E. Akbas, Z. Yildirim, and S. Yologlu. 2006. "Legionnaire's Disease: A Nosocomial Outbreak in Turkey." Journal of Hospital Infections 62:50-57.

Pancer, K., D. Rabczenko, and H. Stypulkowska-Misiurewicz. 2006. "The Influence of Contamination of a Hospital Hot-Water System with Legionella Pneumophila on Serum Antibody Production by Staff Members." Indoor Built Environment 15: 105-109.

Rafiee, M., M. Jahangiri-rad, H. Hajjaran, A. Mesdaghinia, and M. Hajaghazadeh. 2014. "Detection and Identification of Legionella Species in Hospital Water Supplies Through Polymerase Chain Reaction (16S rRNA)." Journal Environmental Health Science and Engineering 12: 83.

Scaturro, M., I. Dell'eva, F. Helfer, and M.L. Ricci. 2007. "Persistence of the Same Strain of Legionella Pneumophila in the Water System of an Italian Hospital for 15 Years." Infection Control Hospital Epidemiology 28: 1089-1092.

Schenck, K.M., M. Sivaganesan, and G.E. Rice. 2009. "Correlations of Water Quality Parameters with Mutagenicity of Chlorinated Drinking Water Samples." Journal Toxicology Environmental Health A 72: 461-467.

Sehulster, L.M., M.J. Arduino, J. Carpenter, R. Donlan, D. Ashford, R. Besser, B. Fields, et al. 2003. Guidelines for Environmental Infection Control in Health-Care Facilities, Recommendations of $\mathrm{CDC}$ and the Health-Care Infection Control Practices Advisory Committee (HICPAC) Department of Health and Human Services, Ed. Chicago, IL: American Society for Healthcare Engineering/ American Hospital Association: CDC's Division of Healthcare Quality Promotion's Internet. p. 235. 
Stewart, P.S., G.A. McFeters, and C.-T. Huang. 2000. “Biofilm Control by Antimicrobial Agents.” In Biofilms, 2nd ed. edited by J.D. Bryers, 373-405. New York: John Wiley \& Sons.

Tesauro, M., A. Bianchi, C. Consonni, F. Pregliasco, and M.G. Galli. 2010. "Environmental Surveillance of Legionella Pneumophila in Two Italian Hospitals." Annali Dell Istituto Superiore Di Sanita 46: 274-278.

van der Kooij, D., H.R. Veenendaal, and W.J. Scheffer. 2005. "Biofilm Formation and Multiplication of Legionella in a Model Warm Water System with Pipes of Cooper, Stainless Steel and CrossLinked Polyethylene." Water Research 39: 2789-2798.

Vorbeck-Meister, I., R. Sommer, F. Vorbeck, and W.H. Hõrl. 1999. "Quality of Water Used for Haemodialysis: Bacteriological and Chemical Parameters.” Nephrology Dialysis Transplantation 14: 666-675.

Wingender, J., and H. Flemming. 2011. "Biofilms in Drinking Water and Their Role as Reservoir for Pathogens." International Journal Hygiene Environmental Health 214: 417-423.

WCC (World Chlorine Council). 2008. "Drinking Water Chlorination.” Position paper. World Chlorine Council. http://www.worldchlorine.org/wp

Yu, V.L. 2008. "Cooling Towers and Legionellosis: A Conundrum with Proposed Solutions.” International Journal Hygiene Environmental Health 211: 229-234.

Zhang, Z., C. McCann, J.E. Stout, S. Piesczynski, R. Hawks, R. Vidic, and V.L. Yu. 2007. "Safety and Efficacy of Chlorine Dioxide for Legionella Control in a Hospital Water System.” Infection Control Hospital Epidemiology 28: 1009-1012. 